\title{
Endorphins in Anti-Aging Activity - Holistic Approach an Emerging Concept
}

\author{
Shrihari TG* \\ Department of Oral Medicine and Oral Oncology, India \\ *Corresponding author: Shrihari TG, Assistant professor, Department of Oral Medicine and Oral Oncology, India

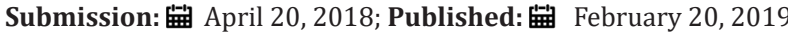

\begin{abstract}
Endorphins are endogenous morphine, neuropeptide. There are three types of endorphins such as beta-endorphins, enkephalins, dynorphins are produced during stress and pain. Receptors of endorphins are situated on nervous system and immune cells. It has got various activities such as immune stimulatory, anti-inflammatory, and delay aging by reduction of free radicals (ROS, RNS) production by immune cells during oxidative burst. This article brief's about the novel roles of endorphins in anti-aging activity.
\end{abstract}

Keywords: Stress; NF-KB; Free radicals; Telomeres

\section{Introduction}

Endorphins are endogenous morphine, neuropeptide, produced in response to stress and pain. There are three types of endorphins such as Beta-endorphins, enkephalins, dynorphins binds to $\mathrm{mu}$, kappa, and delta receptors. Receptors of endorphins are present on nerves and immune cells. Beta endorphins is an abundant, potent endorphin than morphine, it is synthesized and stored in the anterior pituitary gland, is a precursor of pro-opiomelanocortin (POMC). Endorphins are produced during mindful meditation, pranayama, intense physical exercise creates a psychological relaxed state known as 'Runners high ', Sex,Tender, Love, care [1-5].

\section{Endorphins in anti-aging activity}

In an inflammatory state, endorphin receptors are increased on the peripheral nerves and immune cells. Binding of beta-endorphin to its $\mu$ receptors situated on the nervous system and immune cells results in production of anti-inflammatory cytokines such as IL-10, IFN- $\gamma$, and TGF- $\beta$ to reduce inflammation. The current concept of aging by release of ROS and RNS free radicals from inflammatory cells such as neutrophils, macrophages, and dendritic cells during oxidative stress via NADPH oxidase pathway leads to cell aging, gene mutation, tissue damage, chronic inflammation, and cell death.

Chronic psychological stress induced release of CRH (Corticotropin releasing hormone) from hypothalamus activate HPA-axis through autonomic nervous system (ANS) release cortisol, noradrenaline, ACTH neuropeptides activate IL-1 $\beta$, TNF- $\alpha$, COX-2, and IL-6 inflammatory mediators, which further activates NF-KB and STAT-3 key transcription factors involved in chronic inflammation mediated release of free radicals such as (ROS,RNS) involved in cell aging, DNA damage, tissue damage, and cell death [2-8].
In the CNS, binding of beta-endorphin to its $\mu$ receptors situated on the central nervous system results in inhibition of GABA inhibitory neurotransmitter, produce dopamine neurotransmitter involved in analgesic activity, euphoria, cognitive development, self reward, stress buster activity (tranquility of mind) and addiction. Anti-inflammatory activity of endorphins especially beta-endorphins is by stress buster activity (Tranquility of mind). Another mechanism of beta-endorphins anti-aging activity by lengthening telomeres which otherwise shorten with aging $[1,3,4]$.

\section{Conclusion}

Endorphins are neuropeptides, synthesized and stored in the pituitary gland in response to stress and pain. Beta-endorphins are abundant endorphins produced in anterior pituitary gland, is a precursor of pro-opiomelanocortin. It has produced in anterior pituitary gland, is a precursor of pro-opiomelanocortin. It has got various activities such as anti-inflammatory, immune stimulatory activities, anti-aging activity by reduction in the production of free radicals (ROS,RNS) and lengthening telomeres. Thorough understanding of the endorphins, their mechanism of action, and their role in anti-aging activity helpful for future holistic, promotive, preventive, and therapeutic approach to delay aging without adverse effects and inexpensive..

\section{References}

1. Shrihari TG (2017) Quantum healing approach to new generation of holistic healing. Transl Med 7(3): 198.

2. Archana S, Deepali V (2014) Endorphins: Endogenous opioid in human cells. World journal of pharmacy and pharmaceutical sciences 4(1): 357374 . 
3. Shrihari TG (2017) Endorphins on cancer: A novel therapeutic approach J carcinog Mutagen 8: 298.

4. Shrihari TG (2017) Quantum healing - A novel current concept of holistic healing. International journal of complementary and alternative medicine 10(2): 329.

5. Sedlmeir P, Eberth J, Schwar ZM, Zimmermann D, Haarig F, et al. (2012) The psychological effects of meditations: A meta -analysis. Psychol Bull 138: 1139-1171.
6. Naghmeh HA, Michael M, Amita KH, Nicholas shaw P, Peter JC (2014) Front Biotransformation of beta- endorphin and possible therapeutic frontiers. Pharmacol 19(1): 1-8.

7. Nani M, Irwin MR, Chung M, Wang C (2014) The effect of mind -body therapies on the immune system -Meta analysis. P Los One 9(7): 10-24.

8. Zhang, Chang Q (2013) Role of Beta-endorphin in control of stress and cancer progression in fetal alcohol exposed rats. Thesis.
Creative Commons Attribution 4.0 International License

For possible submissions Click Here

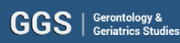

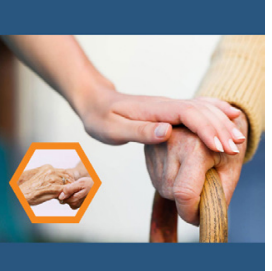

\section{Gerontology \& Geriatrics Studies}

\section{Benefits of Publishing with us}

- High-level peer review and editorial services

- Freely accessible online immediately upon publication

- Authors retain the copyright to their work

- Licensing it under a Creative Commons license

- Visibility through different online platforms 